\author{
Volume 7 No. 1, Juni 2020 \\ P-ISSN: 2406-808X // E-ISSN: 2550-0686 \\ https://journal.iainlangsa.ac.id/index.php/ikhtibar \\ https://doi.org/10.32505/ikhtibar.v7i1.610
}

\title{
KONSEP PENDIDIKAN MULTIKULTURAL DALAM ISLAM
}

\author{
Teuku Amnar Saputra \\ UIN Sunan Kalijaga Yogyakarta \\ teukuamnar@gmail.com
}

\begin{abstract}
Abstrak
Indonesia sebagai negara yang multikultural sangat berpotensi menimbulkan konflik dalam masyarakat. Islam sebagai agama mayoritas harus mampu menjadi rahmatan lil alamin bagi seluruh rakyat Indonesia. Penelitian ini bertujuan untuk membahas tentang landasan ontologi dan epistemologi pendidikan multikultural serta bagaimana konsep dan landasan pendidikan Multikultural dalam Islam. Pendidikan multikultural merupakan sebuah konsep yang sangat baik di terapkan dalam dunia pendidikan di Indonesia yang sangat pluralis ini. Tujuan dari pendidikan multikultural itu sendiri adalah untuk menjadikan siswa yang pluralis serta mampu meminimalisirkan konflik suku, ras, budaya dan agama. Konsep pendidikan Multikultural merupakan sebuah konsep yang sudah sangat sesuai dengan esensi ajaran Islam sebagai agama yang rahmatan lil'alamin dan sangat menghargai keberagaman yang ada di dunia ini sebagaimana tersebutkan dalam Firman Allah Swt. dalam surat Al-Hujurat ayat 13.
\end{abstract}

Kata Kunci : Pendidikan, Multikultural, Islam

\begin{abstract}
Indonesia as a multicultural country has the potential to cause conflict in society. Islam as the majority religion must be able to be rahmatan lil alamin for all Indonesian people. This study aims to discuss the ontology and epistemology foundation of multicultural education and how the concept and foundation of Multicultural education in Islam. Multicultural education is an excellent concept applied in the very pluralistic world of education in Indonesia. The purpose of multicultural education itself is to make students pluralistic and able to minimize ethnic, racial, cultural and religious conflicts. The concept of Multicultural education is a concept that is very in accordance with the essence of the teachings of Islam as a religion that is rahmatan lil'alamin and very appreciates the diversity that exists in this world as Firman Allah Swt. in Surah Al-Hujurat ayat 13.
\end{abstract}

Keywords: Education, Multicultural, Islam 


\section{Pendahuluan}

Kemajemukan yang terjadi dalam masyarakat yang plural dengan berbagai latar belakang keagamaan sangat berpotensi menimbulkan konflik antara kelompok. ${ }^{1}$ Indonesia sebagai negara yang besar dan terdiri dari berbagai macam suku, ras, budaya dan agama sangat berpotensi timbulnya konflik antar sesama. Terutama dalam hal keberagaman agama, analisa yang ditunjukkan oleh Taufik Saefuddin mengatakan bahwa hampir sebagian konflik horizontal yang terjadi di Indonesia dilatarbelakangi oleh agama. ${ }^{2}$ Konflik juga dapat disebabkan oleh adanya yang mendominasi dalam sebuah kelompok, dalam kasus demokrasi mayoritas selalu memiliki panggung yang kuat dalam mempengaruhi. Sehingga dominasi politik dan agama juga mampu menumbuhkan benih-benih konflik dalam masyakarakat. ${ }^{3}$

Indonesia sebagai negara yang terdiri dari beragama suku, ras dan agama sangat harus memperhatikan konsep pendidikan multikultural dalam setiap lini pendidikan yang dijalankan. Islam sabagai agama mayoritas menjadi dominasi dalam setiap kebijakan dan ketentuan. Islam memiliki konsep Rahmatan Lil'alamin sangat mengedepankan kemaslahatan umatnya. Tidak hanya itu, Muslim yang sesungguhnya juga harus mampu menjadi rahmat bagi diri dan lingkungannya sehingga siapa pun yang berada di sekitarnya mampu merasa aman.

Dalam menciptakan pribadi Muslim yang baik dan berkualitas, pendidikan memiliki peran yang begitu penting dalam prosesnya individu menjadi manusia dewasa. Pendidikan sudah didapatkan dari pertama manusia dilahirkan yakni dalam lingkungan keluarga yang kemudian kepada level yang lebih tinggi yaitu di lembaga pendidikan seperti sekolah, pesantren dan universitas. Munculnya fenomena-fenomena radikalisme dan terorisme belakangan ini kian mengancam nama baik Islam dah keutuhan bangsa yang beragam ini. Kemajemukan dan keberagaman etnis, budaya dan agama adalah hal yang tidak dapat dihindari dan harus diterima oleh masyarakat umum.

Konsep pendidikan multikultural dianggap sangat tepat untuk menekan konflikkonflik yang terjadi di tengah masyarakat yang majemuk ini. Pendidikan multikultural juga senada dengan tujuan agama Islam yang sangat menghargai. Penelitian ini bertujuan untuk membahas tentang landasan ontologi dan epistemologi pendidikan multikultural serta bagaimana konsep dan landasan pendidikan Multikultural dalam Islam.

\section{Ontologi Pendidikan Multi Kultural}

Perkembangan dan peningkatan penduduk dunia dan globalisasi telah menciptakan masyarakat yang pluralis. Kemajemukan yang terjadi dalam masyarakat membuat semuanya memiliki latarbelakang yang berbeda baik dari aspek wilayah, pendidikan maupun agama. Kemajemukan merupakan sesuatu yang tidak dapat dihindari, karena manusia semakin berkembang dengan pesat. Kemudahan transformasi dan komunikasi membuat akses tanpa batas yang menyebabkan polah hubungan yang hanya membutuhkan waktu yang sangat singkat. Kondisi seperti ini telah menciptakan masyarakat yang beragam

\footnotetext{
${ }^{1}$ Hermana Somantrie, “Konflik Dalam Perspektif Pendidikan Multikultural,” Jurnal Pendidikan Dan Kebudayaan 17, no. 6 (2011): 660-672.

2 Taufiq Saefuddin, “Memahami Konflik Antar Iman: Menyikapi Perbedaan Sebagai 'Rahmat' Dan Bukan 'Konflik,'” Jurnal Al Adyaan; Jurnal Sosial Dan Agama 1, no. 02 (2016).

${ }^{3}$ Bungaran Anton Simanjuntak, "Strategi Dominasi Dan Keutuhan Negara Bangsa Yang Pluralistik," 2005.
} 
dan berpotensi terhadap timbulnya konflik antar sesama. ${ }^{4}$ Sehingga atas dasar ini dengan dilakukannya penelitian oleh para ahli yang kemudian mendesa PBB melalui UNESCO untuk segera mengimplentasikan pendekatan multikultural dalam pendidikan. ${ }^{5}$

Pendidikan adalah proses yang terdiri dari adanya pengajar dan adanya yang diajar dimana tujuannya untuk membentuk manusia sebagaimana yang diharapkan pendidik. Dalam prosesnya pendidikan menurut Darmaningtyas membutuhkan sebuah usaha sadar dan sistematis. ${ }^{6}$ Pembentukan tersebut menyangkut daya pikir (Intelektual) dan emosional yang berkaitan dengan hubungan manusia dengan sesamanya. ${ }^{7}$ Amos Neolaka dan Grace Amialia A.N mendefinisikan kedalam dua pengertian Pertama pendidikan adalah latihan dan Kedua pendidikan merupakan sebuah proses mempelajarkan peserta didik agar mampu mengenali dirinya sendiri dan kemudian dapat menggali potensi yang ada dalam dirinya. ${ }^{8}$ Definisi ini menunjukkan bahwa adanya sebuah proses penggalian potensi yang kemudian dapat diimplementasikan dalam kehidupan nyata, proses tersebut yang kemudian diaplikasikan dalam bentuk latihan-latihan. Pendidikan adalah sebuah upaya untuk memanusiakan manusia, memanusiakan berarti menjadikan manusia yang seutuhnya sebagaimana tujuan manusia itu sendiri diciptakan. ${ }^{9}$

Pendidikan multikultural jika di definisikan dalam segi bahasa terdiri dari dua gabungan kata, yaitu "pendidikan" sebagaimana yang telah di definisikan di atas dan kata "multikultural". Secara etimologi istilah ini dapat di definisikan dalam dua kata yang terpisah yaitu "multi" dapat diartikan banyak atau plural sendangkan kata "Kultural" dapat dipahami sebagai kultur atau budaya. Terakhir isltilah "Isme" di akhri kata memiliki pengertian paham maupun aliran. ${ }^{10}$ Secara sederhana pendidikan multikultural merupakan pendidikan yang mencoba memperkenalkan peserta didik kepada keberagaman kultur atau budaya. Samrin dalam definisinya mengenai pendidikan mulitkultual mengatakan bahwa perlunya ada usaha secara sadar dalam mengembangkan kepribadian internal maupun eksternal sekolah yang mencakup status sosial, ras, suku dan agaman sehingga terciptanya kecerdasan dalam kepribadian yang mampu menghadapi berbagai permasalahan dalam hal keberagaman. ${ }^{11}$ Hal senada juga di ungkapkan oleh Iis Arifuddin yang menekan kepada proses dalam menanamkan nilai serta cara hidup yang mampu menghormati, bersikap tulus, dan mampu bertoleransi terhadap keberagaman masyarakat. ${ }^{12}$ Tujuannya adalah agar manusia mampu menghargai keberagaman budaya, etnis, suku, dan aliran (agama). ${ }^{13}$

\footnotetext{
${ }^{4}$ Murniati Agustian, Pendidikan Multikultural (Penerbit Unika Atma Jaya Jakarta, 2019), 4.

5 Agustian, 6.

${ }^{6}$ Naim Ngainun and Achmad Sauqi, Pendidikan Multikultural: Konsep Dan Aplikasi, Cet. 1 (Depok, Sleman, Jogjakarta: Ar-Ruzz Media : Didistribusikan oleh Ar-Ruzz Media Group, 2008), 29.

${ }^{7}$ Syaiful sagala, Etika \& Moralitas Pendidikan: Peluang dan Tantangan (Prenada Media, 2013), 38.

8 Amos Neolaka and Grace Amialia A. Neolaka, Landasan Pendidikan Dasar Pengenalan Diri Sendiri Menuju Perubahan Hidup: Edisi Pertama (Kencana, 2015), 3.

${ }^{9}$ Prayitno, Dasar Teori dan Praksis Pendidikan (Grasindo, 2009), 24.

${ }^{10}$ Warsito Ronggo, "Pendidikan Multikultural," Jurnal Tribakti 21, no. 1 (January 2010): 3.

${ }^{11}$ Samrin Samrin, "Konsep Pendidikan Multikultural," Al-TA'DIB 7, no. 2 (July 1, 2014): 120-40, https://doi.org/10.31332/atdb.v7i2.321.

12 Iis Arifudin, "Urgensi Implementasi Pendidikan Multikultural Di Sekolah,” Insania 12, no. 2 (MeiAgustus 2007): 220-33.

${ }^{13}$ Rustam Ibrahim, "Pendidikan Multikultural: Pengertian, Prinsip, Dan Relevansinya Dengan Tujuan Pendidikan Islam,” ADDIN 7, no. 1 (November 14, 2015), https://doi.org/10.21043/addin.v7i1.573.
} 


\section{Tujuan Pendidikan Multi Kultural}

Konsep Pendidikan Multikultural juga senada dengan tujuan pendidikan itu sendiri sebagaimana yang tertuang dalam UU Nomor 20 tahun 2003 tentang Sistem Pendidikan Nasional, Pasal 3. ${ }^{14}$ Prayitno menjelaskan bahwa tujuan-tujuan pendidikan tersebut tergambarkan dalam dimensi-dimensi penciptaan manusia, yaitu : Pertama Dimensi kefitrahan yang berorientasi kepada kebenaran dan keluhuran, Kedua dimensi Individual yang menekan kepada aspek potensi dan perbedaan dengan yang lain. Ketiga dimensi kesosialan dimana manusia akan berkomunikasi dengan sesama dalam kebersamaan. Keempat dimensi kesusilaan yang terkandung di dalamnya nilai dan moral, dan Kelima dimensi keberagaman yaitu iman dan taqwa dengan menjunjung tinggi keberagaman adalah haknya sang pencipta. ${ }^{15}$

Dilihat dari Tujuan pendidikan itu sendiri, pendidikan multikultural sangat penting untuk di terapkan. Keberagaman budaya dan agama menjadikan multikultural sebagai konsep yang sangat tepat untuk di terapkan. Keberagaman tersebut tidak dapat dihindari karena terbentuknya masyarakat yang dalam realitanya terdiri dari beragam macam suku ras, agama dan budaya. Pendidikan dengan menggunakan pendekatan multikultural dapat dijadikan sebagai solusi untuk menekan keretakan yang disebabkan oleh keberagaman umat manusia. ${ }^{16}$ Oleh karena itu pendidikan multikultural harus berpijak pada filosofi yang mengedepankan prinsip persamaan (Equality), ${ }^{17}$ dan pada akhirnya akan mampu mewujudkan perdamaian, keadilan, dan persaudaraan sosial, anti konflik, kekerasan dan diskriminatif. $^{18}$

\section{Epistimologi Pendidikan Multikultural}

Epistemologi merupakan sebuah cabang dari Filsafat yang secara ilmiah untuk menjawab bagaimana dalam mencapai kepada ilmu tersebut. Metode yang digunakan juga harus bersifat rasional dan dapat dibuktikan secara empiris. ${ }^{19}$ Begitu juga dengan pendidikan multikultural untuk mendapatkan sebuah klaim kebenaran sebagai sebuah ilmu pendekatan ini harus memiliki cara yang rasional dan sistematis dalam mewujudkan tujuan yang akan di capai.

Pendidikan multikultural memiliki cara pandang tersendiri dalam menyikapi keberagaman. Sehingga ada enam tujuan dari penerapan nilai-nilai pendidikan multi kulrutal yaitu: Mengembangkan beragam perspektif sejarah yang berasal dari kelompokkelompok masyarakat, Memperkuat kesadaran budaya, Memperkuat kompetensi intercultural, membasmi rasisme, mengembangkan kesadaran atas kepemilikan planet bumi serta Mengembangkan aksi sosial. ${ }^{20}$ Adapun ciri-ciri pendidikan multikultural adalah sebagai berikut:

Pertama Memiliki tujuan untuk menjadikan individu dan masyarakat yang berbudaya dan berperadaban. Kedua Materi ajarnya meliputi nilai luhur kemanusiaan,

14 “Undang-Undang Nomor 20 Tahun 2003 Tentang Sistem Pendidikan Nasional, Pasal 3," n.d.

${ }^{15}$ Prayitno, Dasar Teori dan Praksis Pendidikan, 16-19.

${ }^{16}$ Ronggo, "Pendidikan Multikultural."

${ }^{17}$ Ibrahim, "Pendidikan Multikultural."

${ }^{18}$ Ruslan Ibrahim, "Pendidikan Multikultural: Upaya Meminimalisir Konflik Dalam Era Pluralitas Agama," El-Tarbawi 1, no. 1 (2008): 115-27.

${ }_{19}$ Muljamil Qomar, Epistemologi pendidikan Islam: dari metode rasional hingga metode kritik (Erlangga, 2005), 11.

${ }^{20}$ Ngainun and Sauqi, Pendidikan Multikultural, 212-13. 
bangsa dan kelompok etnis. Ketiga Menggunakan metode yang demokratis. Empat Evaluasi dan penilaian perilaku dengan melihat bagaimana persepsi, apresiasi dan tindakan terhadap budaya yang berlainan. ${ }^{21}$

J.A Banks mengemukakan empat pendekatan dalam pendidikan multikultural yaitu Pertama Kontribusi dengan melakukan penyeleksian terhadap buku-buku teks wajib, tujuannya adalah untuk meningkatkan pengetahuan tentang keberagaman kelompok. Kedua Aditif yaitu dengan memasukkan literatur kebudayaan kedalam meaistream kurikulum. Ketiga Transformatif, dengan melakukan pengembangan paradigma kurikulum yang menggunakan pendekatan perbandingan. Dan Aksi Sosial yaitu kombinasi antara pendekatan transformatif dengan aksi dalam berntuk tingkah laku untuk melakukan perubahan sosial. Harapannya dengan melakukan hal ini individu akan mampu dan terampil dalam resolusi konflik atau rekonsiliasi keberagaman dan kebudayaan. ${ }^{22}$

Pengembangan kurikulum pendidikan multikultural bisa dilakukan dengan langkah-langkah berikut ini:

1. Landasan filosofis yang berorientasi kepada kurikulum yang bersifat humanisme, progresivisme dan merekonstruksi sosial.

2. Curriculum Content, yang berisi pemaparan ralita maupun fakta, teori dan pengertian yang mengandung nilai-nilai moral yang harus dimiliki oleh setiap peserta didik.

3. Teori belajar harus memerhatikan keragaman sosial, budaya, ekonomi dan politik sehingga akan menempatkan anak didik sebagai makhluk berjiwa sosial, yang mampu hidup dan selaras dengan masyarakat yang berbeda kebudayaan.

4. Proses belajar harus berdasarkan proses yang memiliki tingkat Ismorphism bisa dilakukan dengan belajar kelompok dan bersaing dalam situasi yang positif.

5. Evaluasi yang harus mencakup semua aspek kemampuan dan kepribadian. Bisa dengan menerapkan penilaian berbasis kelas (PBK) seperti portopolio, catatan, observasi, wawancara, Performance test, proyek dan produk. ${ }^{23}$

Dalam pelaksanaannya, pendekatan multikultural ini tidak hanya melibatkan guru ataupun pihak sekolah saja, Muh Kharis menyatakan ada tiga pihak yang harus terlibat aktif dalam pelaksanaan pendekatan ini. Pertama, penyelenggara pendidikan atau pihak sekolah hendaknya memberikan pemahaman secara komprehensif tentang input, proses, dan output yang akan didapatkan dalam pendekatan multi kultural. Kedua, guru sebagai aktor yang langsung bersentuhan dengan peserta didik harus terlibat secara aktif dan kreatif dalam menyelenggarakan pendidikan multikultural. Ketiga adalah orang tua dan masyarakat secara umum hendaknya berpartisipasi secara aktif dalam penyelenggaraan pendidikan multikultural dengan ikut berpartisipasi dalam program-program sekolah yang membutuhkan partisipasi masyarakat di sekitar sekolah. ${ }^{24}$

Kerja sama seluruh element sangat membantu dalam pencapaian dan penerapan konsep pendidikan multikultural. Kemudian dalam implementasinya di samping penggunaan kurikulum yang berbasis multikultural juga harus di seimbangi dengan

${ }^{21}$ Choirul Mahfud, Pendidikan multikultural (Yogyakarta: Pustaka Pelajar, 2014), 187.

${ }^{22}$ Sulalah, Pendidikan Multikultural (Didaktika Nilai-Nilai Universalitas Kebangsaan (Malang: UINMaliki Press, 2011), 126-28.

${ }^{23}$ Ngainun and Sauqi, Pendidikan Multikultural, 198-99.

${ }^{24}$ Muh Kharis, "Media Pembelajaran Berbasis Multikultural," Ta'allum: Jurnal Pendidikan Islam 2, no. 1 (June 1, 2014): 63-71-71, https://doi.org/10.21274/taalum.2014.2.1.63-71. 
kegiatan-kegiatan penunjang. Sulalah mengatakan bahwa pimpinan lembaga pendidikan maupun keagamaan harus melakukan beberapa kegiatan baik secara rutin maupun insidental. Bentuk kegiatan tersebut dapat berupa : siraman rohani atau ceramah keagamaan yang di ikuti semua elemen, melakukan kegiatan sosial religius dalam masyarakat yang majemuk, memotori forum lintas agama, melibatkan peserta didik menjadi aktif dalam dialog antar agama yang mampu meningkatkan komunikasi antar agama dan budaya serta kegiatan dalam bentuk memberikan dukungan moril maupun materil. ${ }^{25}$

E.Stone berpendapat bahwa setiap lembaga pendidikan harus memiliki tiga unsur dasar dalam mewujudkan kegiatan di atas yaitu; Conditioning force adalah prasarana yang memadai untuk menunjang kegiatan, cognitive force yang merupakan pengintegrasian konsep multikultural kedalam kurikulum maupun dalam mata pelajaran terpisah dan modeling force, yang mengedepankan penyelenggara pendidikan sebagai aktor yang menjadi contoh bagi peserta didik. ${ }^{26}$

\section{Pendidikan Multikultural dalam Islam}

Islam yang Rahmatan Lil'alamin harus mampu menanamkan sikap dan perilaku umatnya senantiasa dalam kebaikan, dan kebaikan yang pada hakikatnya adalah mampu berperilaku baik dalam hubungannya dengan Allah dalam hal ibadah dan berhubungan antara sesama manusia dalam konteks muamalah (Sosial). Keberagaman dari kelompokkelompok manusia juga merupakan sebuah sunnatullah yang harus dijunjung tinggi umat Islam. "Multikultural dalam pandangan Islam adalah sunnatullah yang akan tetap ada dan tidak berubah. Sedangkan sunnatullah bagi penganut Islam adalah keniscayaan yang tak mungkin bisa diingkari." 27 Sebagaimana yang tercermin dalam Al-Quran Al-Hujurat ayat $13^{28}$

"Hai manusia, sesungguhnya Kami menciptakan kamu dari seorang laki-laki dan seorang perempuan dan menjadikan kamu berbangsa-bangsa dan bersuku-suku supaya kamu saling kenal-mengenal. Sesungguhnya orang yang paling mulia diantara kamu disisi Allah ialah orang yang paling takwa diantara kamu. Sesungguhnya Allah Maha Mengetahui lagi Maha Mengenal."

Firman Allah Swt. tersebut menggambarkan bagaimana manusia itu diciptakan pada awalnya yaitu dari satu sumber dan dari seorang individu yang kemudian beranak pinak dan menjadikannya berbangsa-bangsa dan bersuku-suku. Singkatnya manusia secara keseluruhan memiliki nenek moyang yang satu. Heru Suparman mengemukakan bahwa ada empat pesan-pesan yang bersifat multikultural dalam Alquran, diantaranya yaitu:

Pertama bahwa asal penciptaan manusia adalah sama. Kemudian dalam tujuan penciptaan manusia bukan untuk saling membenci, melainkan untuk saling mengenal atau berinteraksi dan kemudian yang membedakan diantara manusia bukan golongan atau sukusuku, melainkan nilai ketaqwaan yang ada pada manusia itu sendiri. Kedua dalam firman tersebut dikatakan bahwa dahulu semua umat terdiri dari satu kesatuan, namun karena

\footnotetext{
25 Pendidikan Multikultural (Didaktika Nilai-Nilai Universalitas Kebangsaan, 136-37.

$26141-44$.

27 Zainal Arifin, "Pendidikan Islam Multikultural Upaya Menumbuhkan Kesadaran Multikultural,"

Al-Insyiroh: Jurnal Studi Keislaman 2, no. 1 (March 16, 2018): 42, https://doi.org/10.35309/alinsyiroh.v2i1.3331.

${ }^{28}$ Al-Quranul Karim, n.d.
} 
terjadinya perselisihan Allah mengutus seorang Rasul-rasul-Nya untuk memberi peringatan dan kabar gembira kepada manusia. Hal ini sebagaimana tergambarkan dalam Alquran Surat al-Baqarah ayat 213. Ketiga Alquran menekankan pentingnya sikap saling percaya, saling mengerti dan saling menghargai antar sesama dan menjauhi segala bentuk berburuk sangka apalagi sampai mencari kesalahan orang lain. Keempat Alquran juga mengharuskan umat Islam untuk mengedepan kedamaian dan memberikan rasa aman bagi seluruh manusia dengan tidak menjadi manusia yang zalim yang dapat memicu terjadinya konflik, sebagaimana yang tergambarkan dalam Alquran surat Asy-Syura ayat 40. ${ }^{29}$

Intisari tersebut sebagaimana yang telah di ungkapkan diatas setidaknya mengambarkan bagaimana perhatian Islam terhadap keberagaman dan pentingnya untuk menjadi insan yang Rahmatan Lil'alamin. Diskusi tentang penting dan kesesuaian pandangan Islam tentang konsep Pendidikan Multikultural sudah banyak dibahas sebelumnya. Semua diskusi mengenai pendidikan multi kultural jika dibawa kedalam Islam bahwa ada dua kecenderungan yang dapat diupayakan dalam mewujudkan tujuan yang hendak dicapai Islam dan pendidikan multikultural. Pertama dengan mengintegrasikan konsep pendidikan multikultural kedalam kurikulum yang diajarkan kepada peserta didik muslim secara keseluruhan mata pelajaran. Kedua dengan berfokus kepada Pendidikan Islam multikultural yang mengajak individu mampu memahami keberagaman dan mampu berperilaku baik dalam menyikapi keberagaman tersebut dan memberi pemahaman bahwa agama yang rahmatanlilalamin harus memberikan kondisi aman dan damai bagi seluruh makhluk ciptaan Allah Swt.

Perpaduan antara multikultural dengan Pendidikan Agama Islam akan bermuara pada upaya penemuan definisi serta tujuan yang sama. Sebagaimana Hasan yang dikutip Zainal Arifin.

"Pendidikan Agama Islam multikultural bertujuan menempatkan multikulturalisme sebagai tujuan dari pendidikan itu sendiri dengan karakter yang bersifat inklusif, demokratis dan humanis serta tidak tercerabut dari sesuatu yang sangat fundamental dari agama Islam, yaitu; al-Qur'an dan as-Sunah". ${ }^{30}$

Kesesuaian antara tujuan yang hendak dicapai tersebut membuat keduanya mampu berjalan dengan baik. Dimana Pendidikan akan mampu menciptakan manusia yang baik dan berakhlakul karimah dengan menghargai perbedaan. Di samping itu juga tujuan dari konsep pendidikan multikultural dapat tercapai.

\section{Penutup}

Pendidikan multikultural sebuah konsep dalam pendidikan yang mengupayakan peserta didiknya untuk dapat hidup toleran dan mampu menghargai keberagaman yang ada dalam dunia ini. Konsep pendidikan multikultural merupakan konsep yang sangat sesuai dengan tujuan Islam itu sendiri yaitu menjadi rahmat bagi sekalian alam. Dalam Islam konsep multikultural dipandang sebagai Sunnatullah karena keberagaman itu sendiri terjadi atas kehendak Allah yang menciptakan manusia dari diri yang satu kemudian menjadikannya berkembangbiak.

${ }^{29}$ Heru Suparman, "Multikultural dalam Perspektif Alquran," AL QUDS : Jurnal Studi Alquran dan Hadis 1, no. 2 (December 1, 2017): 188-91, https://doi.org/10.29240/alquds.v1i2.250.

${ }^{30}$ Arifin, "Pendidikan Islam Multikultural Upaya Menumbuhkan Kesadaran Multikultural," 52. 
Ada dua cara yang dapat diupayakan dalam mengimplementasikan konsep pendidikan multikultural, yaitu dengan mengintegrasikan segala mata pelajaran dengan konsep multikultural atau dengan menyediakan ruang kuhus dalam artian mata pelajaran khusus untuk pendidikan multikultural.

\section{Daftar Pustaka}

Agustian, Murniati. Pendidikan Multikultural. Penerbit Unika Atma Jaya Jakarta, 2019. Al-Quranul Karim, n.d.

Amos Neolaka, and Grace Amialia A. Neolaka. Landasan Pendidikan Dasar Pengenalan Diri Sendiri Menuju Perubahan Hidup: Edisi Pertama. Kencana, 2015.

Arifin, Zainal. "Pendidikan Islam Multikultural Upaya Menumbuhkan Kesadaran Multikultural.” Al-Insyiroh: Jurnal Studi Keislaman 2, no. 1 (March 16, 2018): 38-56. https://doi.org/10.35309/alinsyiroh.v2i1.3331.

Arifudin, Iis. "Urgensi Implementasi Pendidikan Multikultural Di Sekolah." Insania 12, no. 2 (Mei-Agustus 2007): 220-33.

Ibrahim, Ruslan. "Pendidikan Multikultural: Upaya Meminimalisir Konflik Dalam Era Pluralitas Agama." El-Tarbawi 1, no. 1 (2008): 115-27.

Ibrahim, Rustam. "Pendidikan Multikultural: Pengertian, Prinsip, Dan Relevansinya Dengan Tujuan Pendidikan Islam.” ADDIN 7, no. 1 (November 14, 2015). https://doi.org/10.21043/addin.v7i1.573.

Kharis, Muh. "Media Pembelajaran Berbasis Multikultural.” Ta'allum: Jurnal Pendidikan Islam 2, no. 1 (June 1, 2014): 63-71-71. https://doi.org/10.21274/taalum.2014.2.1.63-71.

Mahfud, Choirul. Pendidikan multikultural. Yogyakarta: Pustaka Pelajar, 2014.

Ngainun, Naim, and Achmad Sauqi. Pendidikan Multikultural: Konsep Dan Aplikasi. Cet. 1. Depok, Sleman, Jogjakarta: Ar-Ruzz Media : Didistribusikan oleh Ar-Ruzz Media Group, 2008.

Prayitno. Dasar Teori dan Praksis Pendidikan. Grasindo, 2009.

Qomar, Muljamil. Epistemologi pendidikan Islam: dari metode rasional hingga metode kritik. Erlangga, 2005.

Ronggo, Warsito. "Pendidikan Multikultural." Jurnal Tribakti 21, no. 1 (January 2010): $1-13$.

Saefuddin, Taufiq. "Memahami Konflik Antar Iman: Menyikapi Perbedaan Sebagai 'Rahmat' Dan Bukan 'Konflik."' Jurnal Al Adyaan; Jurnal Sosial Dan Agama 1, no. 02 (2016).

Samrin, Samrin. "Konsep Pendidikan Multikultural.” Al-TA'DIB 7, no. 2 (July 1, 2014): 120-40. https://doi.org/10.31332/atdb.v7i2.321.

Simanjuntak, Bungaran Anton. "Strategi Dominasi Dan Keutuhan Negara Bangsa Yang Pluralistik," 2005.

Somantrie, Hermana. "Konflik Dalam Perspektif Pendidikan Multikultural." Jurnal Pendidikan Dan Kebudayaan 17, no. 6 (2011): 660-672.

Sulalah. Pendidikan Multikultural (Didaktika Nilai-Nilai Universalitas Kebangsaan. Malang: UIN-Maliki Press, 2011.

Suparman, Heru. "Multikultural dalam Perspektif Alquran." AL QUDS : Jurnal Studi Alquran dan Hadis 1, no. 2 (December 1, 2017): 185-204. https://doi.org/10.29240/alquds.v1i2.250. 
Syaiful sagala. Etika \& Moralitas Pendidikan: Peluang dan Tantangan. Prenada Media, 2013.

"Undang-Undang Nomor 20 Tahun 2003 Tentang Sistem Pendidikan Nasional, Pasal 3," 